time I was there none appeared to be doing any damage. Among. the Lepidoptera that were bred from caterpillars I may mention a Syntomid, Cyanopepla submacula Walk. (det. Dyar). The Skipper Perimeles remus Fabr. was very common in the fields. A few caterpillars belonging to the genus Cirphis, which commonly eat the unfolding leaf of the cane were attacked by the parasite, Horismenus urichi Crawford (det. Crawford). From the eggs of an undetermined Fulgorid imbedded in the tissue of a cane leaf, I reared a giant $\mathrm{My}$ marid which turned out to be Cosmocomoidea morrilli Howard (det. Howard).

There were numbers of lizards of different species in the fields, which do good work in keeping down insects of all kinds. On reference to Plate 7 it will be readily understood how impossible would be artificial control, such as spraying in a sugar cane field, when canes are any size at all. The only time of the year would be when the canes have just commenced to grow, but then two difficulties crop up, the scant labor supply and the large areas to be treated at one and the same time. Planters must therefore rely on natural control and in Mexico there is a fair amount of it by insects and fungi.

My thanks are due to Dr. Howard and his assistants and to Lt.Col. Winn Sampson for determinations.

\title{
THE SUGAR-CANE TINGID FROM MEXICO
}

\section{By Otto Heidemann}

This neat little hemipterous insect was originally described as $\mathrm{MO}_{\mathrm{O}}$ nanthia tabida and figured by Herrich Schaeffer 1839, habitat Mexico. F. K. Fieber copied Schaeffer's description and figure in his "Monographie der Tingidex," 1844. Later, about 1900, Dr. G. C. Champion found specimens of this species also in Panama and Guatemala and redescribed and figured the same in the Biologia Centrali-Americana, but referred the species to the genus Leptodictya, which had been erected by Stal, 1873, based on some South-American species.

Notwithstanding the fact, that, the characters of the species already are well defined, the writer ventures to give a new description more in particulars.

Leptodictya tabida (H. Schaeff.) Champion. ${ }^{3}$

Monanthia tabida Herrich Schaeffer. ${ }^{1}$

Monanthia tabida Fieber. ${ }^{2}$

1 Wanzenartigen Insecten, V, p. 86, t. 173, fig. 535. (1839).

En. Monogr. Tingidere, 1884, p. 70, t. vi, fig. 1.

- Biol. C. Am. II, p. 23, t. 2, fig. 10. (1897-1901). 
Body elongate oblong, very flat. Head short with five slender spines, those in front nearly extending to beyond the second antennal joint, the other two diverging from the base of head somewhat upwardly. Eyes rather small, globular, reddish, strongly faceted. Buculæ minutely reticulated, the edge hardly upturned. Sides of rostral groove moderately raised; rostrum not quite reaching the metasternum. Antennæ long and rather thin; basal joints about as long as the apical, which is fusiform; second joint very short; third, four times as long as the fourth. Pronotum narrowing anteriorly, the disk hardly convex, with three linear, low carinæ; interspaces finely punctured; the triangular posterior portion of pronotum quite long, pointed at apex, the surface depressed, closely reticulate; the expanded lateral margins of pronotum are formed by two layers of membrane joined together on the outer edge (viewed sideways) which is cut straight and rectangular anteriorly, the lateral margins are somewhat opaque and have two rows of small areoles. Hood short and with a sharp carina on top, projecting a little in front, but not covering the head, finely reticulated. The elytra transparent, elongate-oval in shape, extending to far beyond the abdomen, the sides feebly rounded, narrowing slightly toward the apex; discoidal area very long, reticulate, the inner nervure, bounding the area, more sharply defined than the outer one, another smaller vein passes along the disk nearly parallel to the inner nervures; subcostal margins narrow, biseriate, costal margins a little broader than the discoidal area with irregular rows of hexangular areoles, those nearing the apex of elytra larger; at the sides anteriorly three or four transverse depressions or folds. Integument pale stramineous; pronotum and abdomen ochraceous; antennæ and legs yellowish-white, claws black. Length $3.8 \mathrm{~mm}$; width across the widest part of elytra $1.6 \mathrm{~mm}$.
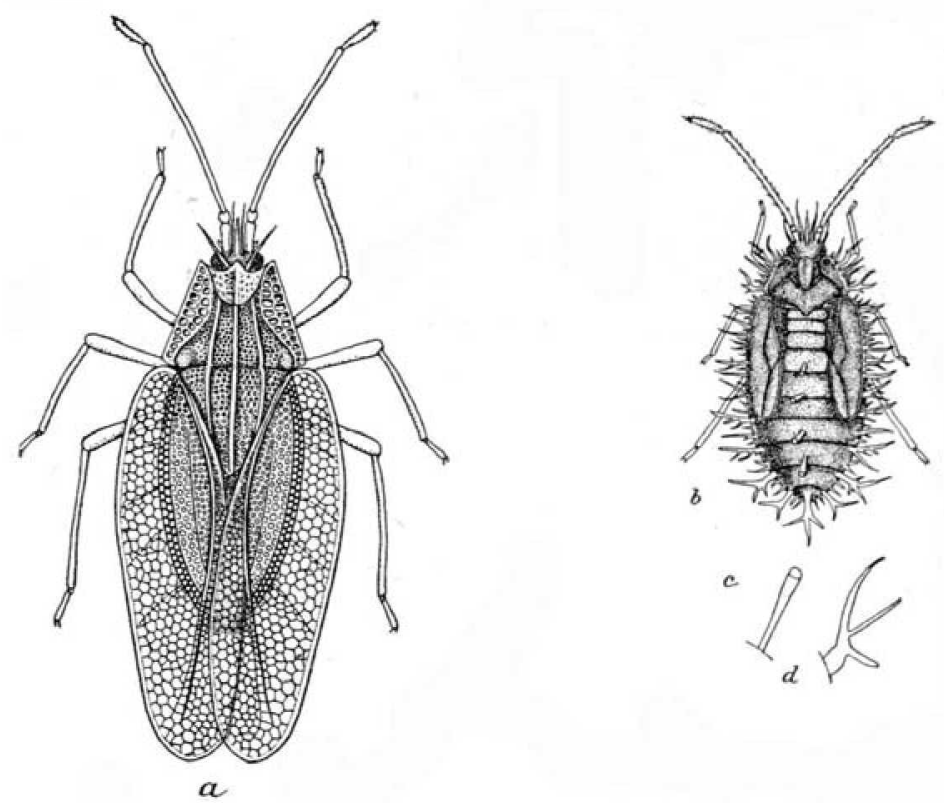

Fig. 1. Leptodictya tabida, $a$, adult; $b$, nymph of same; $c$, club-shaped process; $d$, lateral abdominal branched-spines. 
Description of the nymph.-Body oblong, rather flat, yellowish-white, densely covered with erect white spinules. The head shows five single very prominent spines. Lateral expansion of the pronotal margins and the sides of body armed with stout, whitish, branched-spines, which are irregular in shape, and at the interspaces are some shorter, single ones. Wing-pads quite long and the posterior triangular portion of pronotum very short. Dorsal part of body ornamented with some peculiar club-shaped processes, which show distinctly an opening at apex. Legs and the underside of body whitish, Antennæ pilose. Length, $2 \mathrm{~mm}$; width, $1 \mathrm{~mm}$.

Described from several specimens collected by Mr. F. W. Urich on Sugar Cane at Santa Lucrecia, State of Vera Cruz, Mexico, September, 1911.

This species can be distinguished at once by the straight margin of the lateral expansion of the pronotum, which is in the other CentralAmerican species more or less rounded.

\section{THE INSECTS AFFECTING SUGAR CANE IN PORTO RICO ${ }^{1}$}

By D. L. VAN DrNe, Entomologist, Experiment Station, Porto Rico Sugar Producers' Association, Rio Piedras, P.R.

Sugar cane has been cultivated in the island of Porto Rico for nearly 400 years. It is only within the last half of the past century, however, that insect pests have been noted affecting the crop and only within very recent years that certain species of insects have given concern to the sugar-cane planters. Those best informed on the subject believe that the sugar-cane moth stalk-borer, Diatrca saccharalis Fabr., was introduced into the island in seed cane brought from the British West Indies. It is probable that other species, previously unknown in the island, were introduced in a similar manner, as for example, the leafhopper, Delphax saccharivora Westw, the weevil stalk-borer, Metamasius hemipterus Linn.; the mealy-bug, Pseudococcus sacchari Ckll.; and the scale-insect, Targionia sacchari Ckll. Some of these species have appeared in the cane fields within the memory of those engaged in the growing of sugar cane at the present time and the evidence points to their having been introduced into the island along with shipments of their host plant.

When this station was organized a little over two years ago by the Sugar Producers' Association of Porto Rico, the study of the insects affecting sugar cane was one of the lines of investigation provided for.

The writer is indebted to Señor Agustín Navarrete for the loan of a copy of Dr. A. Stahl's "Fauna de Puerto-Rico" which was published

1 Published by permission of Mr. J. T. Crawley, Director, Experiment Station, Porto Rico Sugar Producers' Association. 